\title{
THE CONCEPT OF SHARING GOODS AS A MANIFESTATION OF INFORMATION TECHNOLOGY TRANSFORMATION IN RURAL AREAS
}

\author{
Dariusz Dudek, Robert Sałek \\ Czestochowa University of Technology, Poland
}

\begin{abstract}
Development of modern information technology and unlimited access to increasingly advanced solutions and mobile tools drives changes in consumer behaviours. Changes have been observed in the traditional consumption model, which has been transformed into cooperation and sharing, with boundaries between consumers and goods manufacturers fading away. The phenomenon of sharing goods is burgeoning with the increasingly popular trend termed sharing economy. The aim of this study is to discuss the role played by involvement of rural inhabitants who follow global trends in the contemporary economy. Furthermore, the survey presented in the study reveals the state of knowledge and awareness of the sharing economy and potential benefits in the form of development of the economy in rural areas.
\end{abstract}

Keywords: sharing economy, rural gminas, information technology

DOI: $10.17512 /$ znpcz.2016.1.12

\section{Introduction}

The increasing globalization and development of modern information technologies have become the drivers of irreversible changes in all aspects of social life. With the development of the information society, the basic principles of competition are now obsolete and outdated (Kulej-Dudek 2014). The objectives and goals of organizational management have changed substantially and led to the emergence of new business models. Access to various products or services is also an important factor. Traditional physical goods are becoming less essential in favour of digital goods. Increasingly wider access to the Internet has caused a substantial increase in the number of products available on demand. Most of the Internet users are willing to use cloud computing and data streaming services. The demand on new competencies in the labour market is also growing and becoming more oriented towards the global economy, with some competencies replaced with others.

The development of education, higher social and economic awareness, changes in work organization and the need for making savings have inspired consumers to search for new solutions adjusted to the demands of the global economy, which affects new attitudes in consumer behaviours. In the 21st century, a major part of society wants to be treated individually, communicate with other users of social networks and choose those with similar interests, tastes or needs. Modern 
technologies support modelling of new communication methods and offer two-way interactive information transfer (Nowakowska-Grunt, Wiśniewska-Sałek 2014). New tools and applications are emerging and new communication channels dedicated to direct recipients are being established. New technologies offer tools for building identity in the virtual world and help exchange both digital and physical resources. The modern economy is based not only on capital and human resources, but also on information that enterprises use (Brzozowska, Bubel 2015).

The development of modern information technologies has forced organizations to process huge amounts of data. The data are collected in the form of databases, data warehouses or they are available in the Internet through social media, chats, discussion boards etc. The data often contain a broad and very important knowledge which cannot be acquired directly by means of conventional methods. With the development of modern information society, the dynamically rising amount of data and information requires using suitable tools to help collect, process, transfer, store and utilize these resources (Kulej-Dudek, pp. 94-105). With technological advances, data are processed to the extent that was unattainable before. Nearly $90 \%$ of all available data have been collected for the last two years. In 2000 , only $25 \%$ of the data were digital while others were in the form of written documents, video recordings, vinyl records, compact cassettes etc. But in 2013, the number reached $98 \%$ of all the data available all over the world. Facebook collects 10 million pictures per hour while Google processes 24 petabytes of data, which represents a thousand times more data than the content of all printed materials collected in the Library of Congress in the USA (Mayer-Schönberger, Cukier, 2014). The amount of information collected is growing four times faster than the economy.

Modern technology offers new solutions to stimulate innovativeness in almost all possible areas of human life. With these solutions, Polish gminas (gminas are principal units of territorial division in Poland), towns or rural areas do not have to fall behind the bigger and developed metropolises in terms of innovations. Social innovations based on new technologies are also crucial in the development of rural areas. Undoubtedly, the best example of this type of innovations is sharing economy.

\section{The evolution of sharing model}

The concept of sharing economy emerged in 1978, when Marcus Felson and Joe L. Spaeth published their book „Community Structure and Collaborative Consumption: A routine activity approach" that started the discussion about sharing goods with other consumers (Felson, Spaeth 1978, pp. 614-624). Sharing economy is based on the human willingness to help each other and share their time and goods, which can be returned in either material on non-material form. This form of collaboration was once limited to the groups of friends, family members or neighbours, but with rapid development of modern technologies, it has grown enormously, with its functions overtaken by organizations that have emerged in the new economy. The sharing economy is mistakenly claimed to be synonymous with 
collaborative economy, peer-to-peer economy, mesh and collaborative consumption. Actually, sharing economy is a much narrower concept compared to collaborative economy as it represents only one of its components. The sharing economy is based on the use of platforms that allow users to share their goods. The sharing economy means a socioeconomic system that encompasses the exchange and cooperation in division of human and material resources in all areas of social and economic life. It involves shared creation, production, distribution, commerce and consumption of goods and services by various people or organizations (Matofska, Sharer 2015).

Despite a long history, the concept of the sharing economy began to be used extensively in the early 2000s. It is obvious that the tendency was driven by the development of modern technologies. This popularity of sharing economy was also caused by the transformations in the economic situation, which consequently led to a global crisis in the late 2000s of the 21 st century. The idea of social responsibility started to be advocated widely to limit environmental degradation. These phenomena caused a substantial improvement in awareness and sensitivity among citizens. The latter became more willing to be involved in the initiatives aimed at popularization of ecological lifestyles and the idea of recycling. This promoted trust and built social responsibility which, with the development of social media, has gained a new meaning: transparency. Through increasingly advanced technologies, the problems of initial lack of trust were overcome and the mechanisms of building reputation of users and transaction safety have been implemented. These activities cause an exponential increase in the interest in sharing services, which could now be provided for individuals who did not know each other before.

From the economic standpoint, sharing, contrary to possession, is much more legitimate and friendly to both environment and society. Sharing resources offers a solution to a number of problems of social character, which often contradict each other, since, on the one hand, we are seeing the excessive consumerism and, on the other hand, extreme poverty. Therefore, a new trend stimulates the development of social capital while it unites users of sharing economy through building and maintaining strong relationships.

\section{Examples of initiatives in the model of sharing economy}

Sharing is a model of consumption which consists in lending, exchange, barter contracts or paid access to goods as opposed to possession ( Gansky 2010, p. 56). The concept of sharing emphasizes making resources available through sharing them (focus on product's function) without the necessity of becoming the owner of the resources. For example, if a person needs to read a book, he or she does not have to buy it but it is enough that we they have access to its contents. There are a plethora of similar solutions used in the sharing economy. Exchange of goods may adopt various forms, from usual exchange between neighbours through various types of services such as e.g. bicycle or car rent or more and more popular access to accommodation. Instead of having goods, contemporary consumers are starting to attach more and 
more importance to functions and experiences connected with the concrete product and, as soon as they use the product, they make it available to others (Botsman, Rogers, 2012, pp. 15-16). Not only does sharing economy limit individual consumption and buying superfluous things but it also strengthens integration and social ties. The economic and social potential, especially in the smallest regions such as rural gminas in Poland, can be noticed by inhabitants of these areas, who know the best what the local resources are. A good example of large-scale sharing initiatives is Stowarzyszenie na Rzecz Rozwoju Gminy Bałtów „Bałt” (Association for the Development of Gmina Battów "Batt"), where commitment of local inhabitants helped eliminate the unemployment in the gmina ( Stowarzyszenie Na Rzecz Rozwoju Gminy Bałtów „BAŁT”, http://www.baltow.info, access on 23rd November 2015.). It was inhabitants who should set the objectives for the development using the concept of sharing and develop scenarios for development in rural gminas, improve their value and use their tourist potential. Similar to Airbnb, where accommodation can be made available in the biggest cities and capital cities, the inhabitants of rural areas can use this platform to offer access to their agritourist farms. This may be an opportunity for many families to earn additional incomes and to start a new way of living. Forbes ( Geron 2015) described an example of a retired photographer, who offers his house twelve times a month via Airbnb at a price of 100 dollars per night, of which he earns 97 dollars. Furthermore, he turns his private car into a cab four times a week making it available via Lyft, earning another 100 dollars a day. There are many similar examples which demonstrate the enormous potential of the sharing economy. Similar to the retired photographer, who earns 3,000 dollars a month without any additional investments, the inhabitants of rural areas can expect additional incomes.

Moreover, the farmer with specialized agricultural equipment can use the SnapGoods services to make it available whenever they do not use it. Other areas which can develop with the idea of sharing economy include wind farms, photovoltaic farms which allow consumers to purchase electrical energy directly from their producers e.g. farmers with wind turbines, biogas plants, water power plants and photovoltaic panels. One example is Vandebron project, where farmers from the northern part of the Netherlands are both energy producers and customers of the enterprise. They have one wind turbine, with installed capacity sufficient to meet the needs of 600 households. Using Vandebron service, customers can choose from the offers that meet their expectations, both in terms of the source of electricity generation and price. Currently Vandebron collaborates with 31 energy producers from renewable sources, with the total capacity meeting the needs of nearly 60,000 households (https://vandebron.nl, as of 23rd November 2015, there were 58,739 households included in the Vandebron project).

\section{Sharing economy in the practice of rural areas}

The issues of the sharing economy are becoming more and more critical to the Polish economy. The main areas where such consumer behaviours are being established are well-developed metropolises, where conscious inhabitants follow 
the trends of the contemporary economy. However, the intention of the authors of this study was to evaluate the knowledge and awareness of inhabitants of rural areas in terms of sharing economy and to indicate potential benefits for the specific region. Furthermore, the aim of the study was to compare views of rural inhabitants on sharing economy and to determine the role which they can play in the development of sharing economy.

The study was based on the methodology of direct interviews using a questionnaire survey at the turn of November 2015. Selection of the research sample was made purposively and randomly among rural gminas. Selection of empirical population was based on a publication ,Area and population in the territorial profile in 2015" prepared by the Central Statistical Office of Poland in Warsaw. Based on this publication, the study group of rural gminas of the Czestochowa powiat (powiats are principal units of territorial division in Poland of the second level) was selected. Selection of the research objects was performed using the methodology of stratified random sampling in order to ensure that various groups that form population are adequately represented. The decision on the size of the research group resulted in the selected gminas from the following assumptions: research sample size of $0.5 \%$ of the statistical population for rural gminas with the number of inhabitants ranging from 0 to 1000 and $0.1 \%$ for gminas with the number of inhabitants of over 1000. Consequently, a set of homogeneous samples was obtained, allowing greater level of accuracy of parameter evaluation (see table 1).

Table 1. General population and research sample for rural gminas

\begin{tabular}{|c|c|c|}
\hline $\begin{array}{c}\text { Rural gminas in the Czestochowa } \\
\text { powiat }\end{array}$ & $\begin{array}{c}\text { General } \\
\text { population* }\end{array}$ & Research sample \\
\hline Dąbrowa Zielona & $\mathbf{3 9 7 2}$ & $\mathbf{4}$ \\
\hline Janów & $\mathbf{5 9 9 1}$ & $\mathbf{6}$ \\
\hline Kamienica Polska & $\mathbf{5 6 5 2}$ & $\mathbf{6}$ \\
\hline Kłomnice & $\mathbf{1 3 7 0 5}$ & $\mathbf{1 4}$ \\
\hline Konopiska & $\mathbf{1 0 7 5 0}$ & $\mathbf{1 1}$ \\
\hline Kruszyna & $\mathbf{4 9 1 0}$ & $\mathbf{5}$ \\
\hline Lelów & $\mathbf{4 9 6 5}$ & $\mathbf{5}$ \\
\hline Mstów & $\mathbf{1 0 7 2 4}$ & $\mathbf{1 1}$ \\
\hline Mykanów & $\mathbf{1 4 8 6 0}$ & $\mathbf{1 5}$ \\
\hline Olsztyn & $\mathbf{7 6 4 9}$ & $\mathbf{8}$ \\
\hline Poczesna & $\mathbf{1 2 7 8 2}$ & $\mathbf{1 3}$ \\
\hline Przyrów & $\mathbf{3 8 6 9}$ & $\mathbf{4}$ \\
\hline Rędziny & $\mathbf{1 0 0 5 5}$ & $\mathbf{1 0}$ \\
\hline Starcza & $\mathbf{2 8 2 6}$ & $\mathbf{3}$ \\
\hline Total & $\mathbf{1 1 9 7 8 8}$ & $\mathbf{1 2 2}$ \\
\hline
\end{tabular}

Source: Author's own elaboration (* as of from 1st January 2015). 
Some 122 inhabitants of the gminas participated in the questionnaire survey. However, 6 participants did not answer all the questions. Therefore, the research sample was reduced to 116 respondents from 14 various rural gminas from the Czestochowa powiat.

Over the half of the research sample were women (57\%), with men accounting for $43 \%$ (Figure 1).

Since most of dedicated platforms for sharing goods are available in the Internet, which excludes inhabitants of rural areas without access to the Internet, the study also evaluated the level of this access. It was found that over $87 \%$ of the respondents from rural areas examined in the study are Internet users, of which almost half (48\%) have access to the Web through mobile devices.

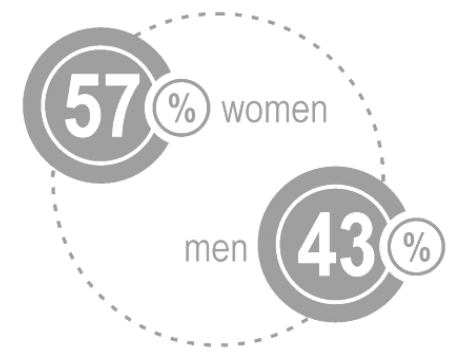

Figure 1. Respondents participating in the survey according to gender

Source: Author's own elaboration.

The main aspect of this study and its aim was to evaluate the level of awareness in terms of sharing economy. Only $18 \%$ of respondents gave positive answer to the question of "Are you familiar with the term sharing economy?" Of this group of respondents, only $3 \%$ of rural inhabitants used services and products available within sharing economy (Figure 2).

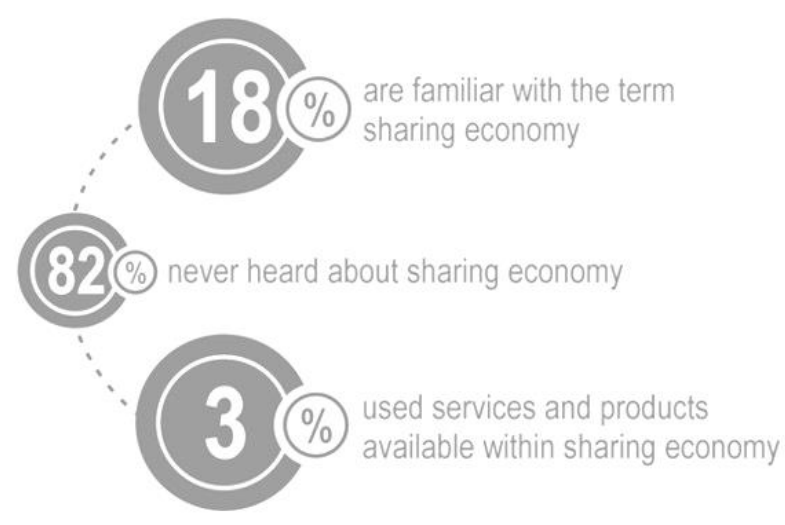

Figure 2. Knowledge of the concept of sharing economy

Source: Author's own elaboration. 
After detailed explanation of the meaning of sharing economy, most of the respondents expressed interest in this topic and the vast majority of them declared the willingness to be involved in the initiatives based on sharing goods (Figure 3).

The overwhelming majority of the respondents said that they can share the goods they have, with more willingness to share them with others or to use shared goods of other people expressed by men $(72 \%)$. The respondents were also asked about the benefits of sharing economy. Almost half of the respondents indicated savings and opportunities to earn additional incomes. Furthermore, it should be noted that inhabitants of rural areas demonstrated awareness of the effect of their consumer behaviours on the natural environment (Figure 4).

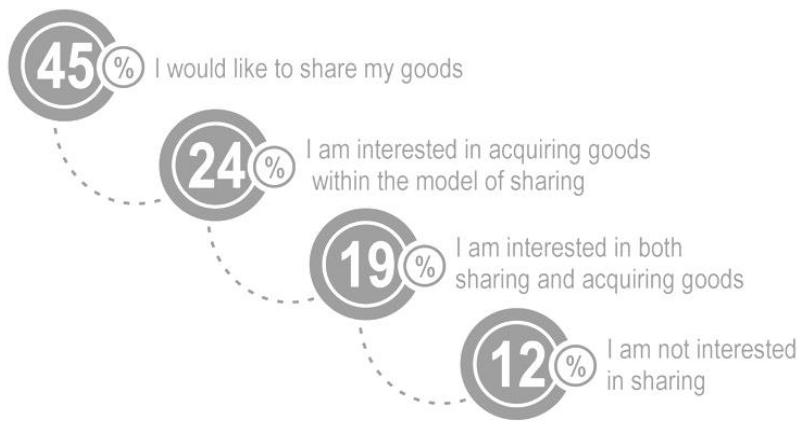

Figure 3. The initiatives based on sharing goods

Source: Author's own elaboration.

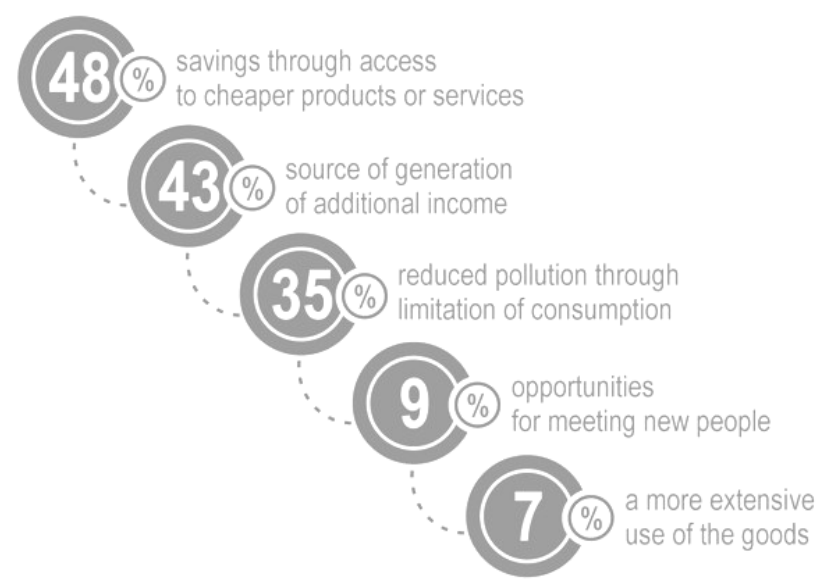

Figure 4. The benefits of sharing economy

Source: Author's own elaboration.

The third most important indication of the respondents was reduction of pollution through limitation of consumption. Less important benefits included opportunities for meeting new people and a more extensive use of the goods. 
Rural inhabitants also notice real benefits for development of the region, with the main catalyst being the concept of sharing goods (Figure 5).

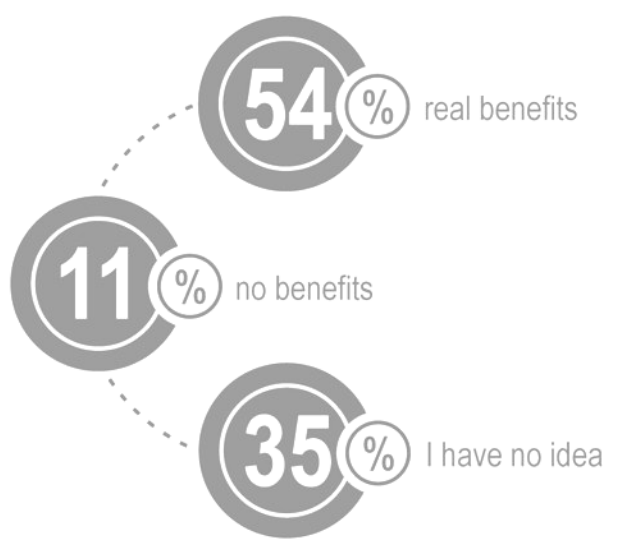

Figure 5. The benefits for development of the region

Source: Author's own elaboration.

The positive answer was given by over the half of the respondents. The vast majority of rural inhabitants did not mention any arguments either for or against popularization of this concept.

\section{Conclusions}

The dynamic development of information technologies has caused a major surge in popularity of sharing economy, a new business model where it is not ownership that counts but rather the opportunities to ensure access to services and goods with no need for being the owner of the goods in order to use them as a consumer or final recipient.

This chapter provided valuable information about the concept of sharing economy, which represents the manifestation of transformation of information technology in rural areas. The findings were used to identify factors that drive development of a new tendency in social economy in the area of the gminas analysed in the study. The sharing economy, viewed by most of the respondents as a beneficial phenomenon (in social, economic and ecological terms), might represent a serious challenge for inhabitants and local leaders in rural areas. The positive features of consumer behaviours that are becoming noticeable in the group analysed in this study reflect the departure from consumerism towards creation of the market space that requires a new strategy for rural areas. An essential challenge for these areas is to adjust to varied expectations and needs of various groups of recipients.

In light of the investigations presented in the study, representatives of individual rural gminas are certain about the future of sharing economy. They are aware and notice real benefits of meeting social and ecological needs. Cooperation of local communities and environmental protection are important values that drive a new 
dimension of global economy. From the standpoint of consumers, responsible management of goods can help substantially reduce expenditures. The benefits are also noticeable for the whole region, improving its image among local inhabitants or potential tourists through the emphasis on the advantages of initiatives aimed at promotion of the concept of sharing goods.

This demonstrates that sharing economy is likely to be developing constantly as it offers such benefits as savings, additional incomes and environmental protection. Another essential value of this concept expressed by the respondents is opportunity to help others and a feeling of association with a more responsible and conscious part of global society.

Undoubtedly, the concept of using the sharing economy model within the rural settings represents a remarkably complex problem of the research, which necessitates further exploration in order to further understanding of this model and to identify the broader set of its determinants.

\section{References}

1. Botsman R., Rogers R., What's Mine Is Yours: The Rise of Collaborative Consumption, Harper Collins, New York 2012, pp. 15-16

2. Brzozowska A., Bubel D., E-business as a New Trend in the Economy, Procedia Computer Science, International Conference on Communication, Management and Information Technology (ICCMIT 2015), Vol.65, Praga, Czech Republic 2015, pp.1095-1104. DOI 10.1016/j.procs.2015.09.043.

3. Felson M., Spaeth J., Community Structure and Collaborative Consumption: A routine activity approach, American Behavioral Scientist, 1978, 21 (March-April), pp. 614-624. DOI 10.1177/000276427802100411.

4. Gansky L., The Mesh: Why the Future of Business Is Sharing, Penguin Books, New York 2010, p. 56.

5. Geron T., Airbnb And The Unstoppable Rise Of The Share Economy, http://www.forbes.com, access on $22^{\text {nd }}$ November 2015.

6. https://vandebron.nl, as of 23rd November 2015, there were 58,739 households included in the Vandebron project

7. Kulej-Dudek E., Managers' Experiences Concerning Knowledge Management in Service Enterprises in the Aspect of Conducted Researches, [In:] Human Resources Management and Ergonomics, Vol.5, nr 1, pp. 94-105.

8. Kulej-Dudek E., Model etapów wzrostu wiedzy pracowników, [in:] Polish: Model for stages in the increase in employee knowledge. Przegląd Organizacji, No. 1 (888) 2014.

9. Matofska B., Sharer Ch., What is the Sharing Economy? http://www.thepeoplewhoshare.com, access on 25th December 2015.

10. Mayer-Schönberger V., Cukier K., Big Data. Rewolucja, która zmieni nasze myślenie, prace $i$ życie, MT Biznes, Warsaw 2014

11. Nowakowska-Grunt J., Wiśniewska-Sałek A., Managing the Local Economy on the Example of the Construction Sector Companies, 6th International Conference on Contemporary Problems of Architecture and Construction, Faculty of Civil Engineering VSB - Technical University of Ostrava, 24th - 27th June, Ostrava, Czech Republic 2014. DOI 10.4028/www.scientific.net/AMR.1020.783.

12. Stowarzyszenie Na Rzecz Rozwoju Gminy Bałtów „BAŁT”, http://www.baltow.info, access on 23rd November 2015. 


\section{KONCEPCJA WSPÓŁDZIELENIA DÓBR JAKO PRZEJAW TRANSFORMACJI TECHNOLOGII INFORMACYJNEJ NA OBSZARACH WIEJSKICH}

Streszczenie: Rozwój nowoczesnych technologii informacyjnych, nieograniczony dostęp do coraz bardziej zaawansowanych rozwiązań i narzędzi mobilnych wywiera ogromne zmiany w dotychczasowych zrachowaniach konsumenckich. Zmianie ulega tradycyjny model konsumpcji, przybierając formę współpracy i współdzielenia, gdzie zacierają się granice między konsumentem a producentem dóbr. Zjawisko współdzielenia dóbr przybiera na sile za sprawą coraz bardziej popularnego trendu, tzw. ekonomii współdzielenia. Celem niniejszego rozdziału jest przedstawienie roli, jaką mogą odegrać mieszkańcy obszarów wiejskich, włączając się w globalny trend współczesnej gospodarki. Ponadto zaprezentowane badania obrazują stan wiedzy i świadomości na temat ekonomii współdzielenia i ewentualne korzyści dla rozwoju gospodarki na terenach wiejskich.

Słowa kluczowe: ekonomia współdzielenia, obszary wiejskie, technologia informacyjna 